\title{
Pemetaan Tesis dalam Aliran-Aliran Filsafat Hukum dan Konsekuensi Metodologisnya
}

\author{
Mahrus Ali \\ Fakultas Hukum Universitas Islam Indonesia \\ Jln. Tamansiswa No. 158 Yogyakarta \\ mahrus_ali@uii.ac.id
}

\begin{abstract}
The main problems in this research: first, how are the theses constructed by the schools in legal philosophy? Second, what are the methodological consequences that emerge dut the different theses of each school in legal philosophy? This research was a normative legal research. The result of the research concluded, first, every law school that exists in legal philosophy has different thesis from one to the other. The thesis of natural law school is the thesis of morality and normativity. Legal realism separates law and moral, and puts more importance on social facts. The thesis of Kelsen's pure theory of law is a synthesis of the thesis of natural law and empirical positivism/legal realism. The thesis of American Sociological Jurisprudence is a synthesis of the legal positivism and the school of history; it separates law and morals as well as the unity between law and fact. Meanwhile, the thesis of utilitarianism is the separation between law and moral as well as the unity between law and fact. Second, the thesis differences in the schools of legal philosophy have consequences on the methodology that is used.
\end{abstract}

Keywords: Morality thesis; normativity; separability; reductive; methodology

\section{Abstrak}

Pokok permasalahan dalam penelitian ini: pertama, bagaimana tesis-tesis yang dibangun oleh aliranaliran dalam filsafat hukum? Kedua, apa konsekuensi metodologis yang ditimbulkan dari perbedaan tesis tiap-tiap aliran dalam filsafat hukum? Penelitian ini merupakan penelitian hukum normatif. Hasil Penelitian menyimpulkan, pertama, tiap-tiap aliran hukum yang berkembang dalam filsafat hukum memiliki tesis yang berbeda satu dengan lain. Tesis aliran hukum alam adalah tesis moralitas dan normatifitas. Realisme hukum memisahkan antara hukum dan moral dan lebih mementingkan fakta sosial. Tesis teori hukum murni Kelsen merupakan sintesis dari tesis hukum alam dan positivisme empiris/realisme hukum. Tesis American Sociological Jurisprudence merupakan sintesis dari positivisme hukum dan mazhab sejarah; ia pemisahan antara hukum dan moral serta penyatuan antara hukum dan fakta. Sedangkan tesis utilitarianisme adalah pemisahan antara hukum dan moral serta kesatuan antara hukum dan fakta. Kedua, perbedaan tesis aliran-aliran dalam filsafat hukum tersebut berkonsekuensi terhadap metodologi yang digunakan.

Kata-kata Kunci: Tesis moralitas; normatifitas; separibilitas; reduktif; metodologi 


\section{Pendahuluan}

Pemikiran hukum ditandai dengan perkembangan pemikiran dalam aliranaliran filsafat hukum. Kemunculan suatu aliran hukum merupakan respon atau kritik terhadap aliran hukum sebelumnya, atau ia muncul sebagai respon terhadap perkembangan sosial masyarakat pada masa itu. Aliran-aliran yang muncul dan berkembang dalam khazanah pemikiran hukum meliputi aliran hukum alam, positivisme hukum (teori hukum murni), utilitarianisme, realisme hukum, american sociological jurisprudence, dan mazhab sejarah. Keenam aliran ini memiliki tesis yang berbeda satu sama lain disebabkan perbedaan cara pandang di dalam melihat realitas (ontologi) yang berimplikasi pada cara bagaimana realitas itu diteliti/ dikaji (metodologi). ${ }^{1}$

Terkait positivisme hukum, Stanley L. Paulson menjelaskan posisi pemikiran hukum Hans Kelsen di antara aliran hukum alam dan positivisme empiris (realisme hukum) dalam bagan berikut ini: ${ }^{2}$

\begin{tabular}{|c|c|c|}
\hline $\begin{array}{l}\text { Fakta } \\
\text { Hukum dan Moral }\end{array}$ & $\begin{array}{c}\text { Tesis Normatifitas } \\
\text { (keterpisahaan hukum } \\
\text { dan fakta) }\end{array}$ & $\begin{array}{c}\text { Tesis Reduktif } \\
\text { (Kesatuan hukum } \\
\text { dan fakta) }\end{array}$ \\
\hline $\begin{array}{l}\text { Tesis Moralitas } \\
\text { (Kesatuan hukum dan moral) }\end{array}$ & Teori Hukum Alam & - \\
\hline $\begin{array}{l}\text { Tesis Separibilitas } \\
\text { (Keterpisahaan hukum dan } \\
\text { moral) }\end{array}$ & $\begin{array}{l}\text { Teori Hukum Murni } \\
\text { Kelsen }\end{array}$ & Positivisme Empiris \\
\hline
\end{tabular}

Bagan di atas menunjukkan bahwa tesis teori hukum murni merupakan sintesis atas tesis aliran hukum alam dan positivisme empiris. Jika tesis aliran hukum alam adalah tesis moralitas (kesatuan hukum dan moral) dan tesis normatifitas (keterpisahaan hukum dan fakta) yang berbeda dengan tesis positivisme empiris berupa tesis separibilitas (keterpisahan hukum dan moral) dan tesis reduktif (kesatuan hukum dan fakta), maka teori hukum murni mengambil satu tesis aliran hukum alam yaitu tesis normatifitas dan satu tesis positivisme

\footnotetext{
${ }^{1}$ Secara teoritis metodologi harus mengacu kepada ontologi. Cara pandang ilmuan terhadap realitas akan mempengaruhi cara bagaimana realitas itu diteliti/dikaji, termasuk bebas atau tidaknya nilai. Baca Egon G. Guba dan Yvonna S. Lincoln, Berbagai Paradigma yang Bersaing dalam Penelitian Kualitatif, dalam Kumpulan Tulisan Norman K. Denzin \& Yvonna S. Lincoln (Editor), Handbook of Qualitative Research, Penerjemah Dariyatno, Badrus Samsul Fata, Abi, John Rinaldi, Pustaka Pelajar, Yogyakarta, 2009, hlm. 133-135

${ }^{2}$ Hans Kelsen, Introduction to the Problem of Legal Theory, diterjemahkan oleh Bonnie Litschewski Paulson dan Stanley L. Paulson, Clarendon Press, Oxford New York, 1992, hlm. xxvi
} 
empiris berupa tesis separibilitas. Sedangkan kotak yang kosong tidak terisi karena jika diisi akan menghasilkan sesuatu yang kontradiktif, sebab tidak mungkin memegang tesis reduktif bersama-sama tesis moralitas. ${ }^{3}$

Kontradiksi antara tesis reduktif bersama-sama tesis moralitas dapat dimengerti jika yang dikaji hanya aliran hukum alam, teori hukum murni dan realisme hukum. Tapi, kontradiksi ini dapat dihilangkan jika yang dikaji tidak hanya ketiganya, melainkan memasukkan juga mazhab sejarah, american sociological jurisprudence dan uilitarianisme. Dalam konteks itulah, penelitian ini mengkaji keenam aliran dalam filsafat hukum tersebut dengan melakukan pemetaan terhadap tesis-tesis yang dibangun dan dikembangkan dan konsekuensi metodologis yang ditimbulkan dengan mengacu kepada bagan yang dibuat Stanley L. Paulson, termasuk kotak kosong yang sengaja tidak diisi.

\section{Rumusan Masalah}

Berdasarkan uraian pada latarbelakang masalah di atas, rumusan masalah dalam penelitian ini sebagai berikut: pertama, bagaimana tesis-tesis yang dibangun oleh aliran-aliran dalam filsafat hukum? Kedua, apa konsekuensi metodologis yang ditimbulkan dari perbedaan tesis tiap-tiap aliran dalam filsafat hukum?

\section{Tujuan Penelitian}

Penelitian ini bertujuan untuk; pertama, mengetahui, menganalisis, dan memetakan tesis-tesis yang dibangun oleh tiap-tiap aliran dalam filsafat hukum; dan kedua, menganalisis konsekuensi metodologis yang ditimbulkan dari perbedaan tesis tiap-tiap aliran dalam filsafat hukum.

\section{Metode Penelitian}

Penelitian ini merupakan penelitian hukum normatif karena yang dikaji adalah asas keadilan dalam sistem moral dengan menfokuskan pada bagaimana ilmuan hukum melihat realitas yang berimplikasi pada cara bagaimana realitas itu diteliti/dikaji. ${ }^{4}$ Penelitian ini melampauai sekat-sekat perundang-undangan yang

\footnotetext{
${ }^{3}$ Jimly Asshiddiqie dan M. Ali Safa'at, Teori Hans Kelsen tentang Hukum, Mahkamah Konstitusi, Jakarta, 2006, hlm. 9-10.

${ }^{4}$ Soetandyo Wigjnosoebroto, Hukum, Paradigma, Metode dan Dinamika Masalahnya, HuMa, Jakarta, 2002, hlm. 147-150
} 
biasa dilakukan dalam penelitian hukum normatif. Penelitian ini sama sekali tidak mengkaji dan menganalisis isi norma perundang-undangan.

Pendekatan yang digunakan adalah pendekatan konseptual dan filosofis. ${ }^{5}$ Pendekatan konseptual mengacu kepada tesis moralitas, tesis separibilitas, tesis normatifitas, dan tesis reduktif dalam filsafat hukum. Sedangkana pendekatan filosofis digunakan karena penelitian ini hendak menganalisis secara mendalam tesis-tesis tiap-tiap aliran dalam filsafat hukum dan konsekuensi metodologisnya.

Bahan hukum penelitian dikumpulkan melalui studi literatur terhadap buku, jurnal dan hasil penelitian terkait aliran-aliran dalam filsafat hukum. Bahan hukum dianalisis secara deskriptif kualitatif. Deskripsi terkait klasifikasi objek berdasarkan kategori-kategori tertentu. Deskripsi merupakan upaya untuk mendeskripsikan variabel-variabel yang diteliti secara mandiri tanpa dikaitkan dengan variabel-variabel lain baik yang bersifat membandingkan maupun menghubungkan. Dalam analisis kualitatif, terdapat tiga alur kegiatan yang terjadi secara bersamaan yaitu reduksi bahan hukum, penyajian bahan hukum, dan penarikan kesimpulan. ${ }^{6}$

\section{Hasil Penelitian dan Pembahasan}

\section{Aliran Hukum Alam; Tesis Moralitas dan Normatifitas}

John Finch menyatakan bahwa terdapat banyak nama yang disematkan kepada aliran hukum alam, seperti hukum alam semesta (the law of universe), hukum Tuhan (the law of God), hukum abadi (the eternal law), hukum umat manusia (the law of mankind), dan hukum akal budi (the law of reason)..$^{7}$ Tesis hukum alam adalah bahwa terdapat hubungan yang esensial antara hukum dan moral (there is an essential connection between law and morality). ${ }^{8}$ Tesis ini, yang disebut dengan tesis moralitas, berimplikasi pada dua hal. Pertama, validitas moral merupakan prasyarat yang dibutuhkan secara logis bagi adanya validitas hukum. ${ }^{9}$ Pernyataan

${ }^{5}$ Johny Ibrahim, Teori dan Metodologi Penelitian Hukum Normatif, BayuMedia Publishing, Malang, 2006, hlm.

${ }^{6}$ Matthew B. Miles dan A. Michael Huberman, Analisis Data Kualitatif, tanpa Penerbit, tt, hlm. 16-20

${ }^{7}$ John Finch, Introduction to Legal Theory, Edisi Kedua, Sweet \& Maxwell, London, 1974, hlm. 21

${ }^{8}$ Jeffrie G. Murphy dan Jules L. Coleman, Philosophy of Law an Introduction to Jurisprudence, Edisi Revisi, Westview Press, London, 1990, hlm. 11.

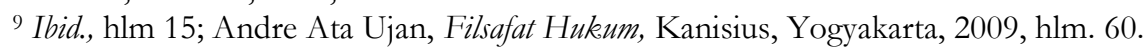


Augustinus bahwa hukum yang tidak adil bukan hukum (an unjust law is not law/lex iniusta non est lex) merupakan gambaran dari hubungan ini. ${ }^{10} \mathrm{Kedua}$, tatanan moral merupakan bagian dari tatanan alam. Aquinas mengatakan: ${ }^{11}$

Law is nothing than an ordinance of reason for the common good, promulgated by him who has the care of the community.... Human law has the nature of law in so for as it partakes of right reason....So far as it deviates from reason, it is called an unjust law and has the nature, not of law, but of violence... Such are acts of violence rather that laws because as Augustine says, a law that is not just seems to be no law at all.

Setiap hukum yang dibuat oleh manusia harus sesuai dengan hukum alam, dalam arti hukum itu harus berasal dari hukum alam. Jika hukum yang dibuat itu ternyata melenceng dari dasar-dasar yang terdapat dalam hukum alam, maka hukum itu disebut hukum yang tidak adil, dan hukum yang tidak adil sesungguhnya merupakan tindakan kekerasan, bukan hukum itu sendiri. ${ }^{12}$

Konsep bahwa hukum yang tidak adil bukan hukum itu sendiri disebabkan oleh pemikiran bahwa hukum merupakan derivasi dari prinsip-prinsip atau kaidah-kaidah moral umum. Artinya, hukum merupakan penjabaran dari prinsipprinsip moral umum yang berlaku secara universal dan mengatasi berbagai kebudayaan. Prinsip-prinsip moral umum menurut aliran hukum alam terdapat dalam moralitas kodrati yang bersumber kepada prinsip-prinsip kodrat alam yang bersifat tetap dan abadi. Prinsip itu disebut pula dngan hukum kodrat (alam) yang mempunyai kedudukan lebih tinggi dari hukum positif. Dengan demikian, hukum positif merupakan derivasi dari hukum kodrat. Ia tidak boleh bertentangan dengan hukum alam. ${ }^{13}$

Tesis lain aliran hukum alam adalah tesis normatifitas, yaitu terpisahnya hukum dari fakta (normativity thesis). ${ }^{14}$ Hukum alam tidak berbicara tentang fakta. Apa yang dimaksud hukum di sini adalah hukum yang digambarkan berlaku abadi, yang norma-normanya berasal dari Tuhan Yang Maha Esa, dari alam

\footnotetext{
${ }^{10}$ Dennis Patterson (editor), A Companion to Philosopby of Law and Legal Theory, Blackwell Publishers, United Kingdom, 1999, hlm. 226

11 Jeffrie G. Murphy dan Jules L. Coleman, Op. Cit., hlm. 15

12 Dennis Patterson, Op. Cit,. hlm. 226

${ }^{13}$ Salman Luthan, "Dialektika Hukum dan Moral dalam Perspektif Filsafat Hukum", Jurnal Hukum Ius Quita Iustum, No. 4, Vol 19, 2012, hlm. 512.

14 Aaron Rappaport, "The Logic of Legal Theory: Reflections on the Purpose and Methodology of Jurisprudence", Mississippi Law Journal, 73, 2004, hlm. 582-583
} 
semesta dan dari akan budi manusia. Sebagai hukum yang kekal dan abadi, begitu jauh tidak terikat oleh waktu dan keadilan dalam tingkatan yang paling mutlak kepada segenap umat manusia. Ia berakar pada batin manusia atau masyarakat dan lepas dari konvensi, undang-undang atau alat kelembagaaan yang lain. ${ }^{15}$

Berdasarkan tesis moralitas dan normatifitas di atas, aliran hukum alam mengkonsepsikan hukum sebagai keadilan dan kebenaran, berlaku secara universal dan abadi. ${ }^{16}$ Keadilan menjadi nilai yang hendak diwujudkan oleh aliran ini, sehingga tidak mengherankan jika metode penelitian aliran hukum alam bernuansa filosofis karena bersifat inklusif, sinopsis, dan reflektif-kritis. Apa yang diasumsikan sebagai benar dengan sendirinya adalah moralitas positif berupa asas-asas kebenaran dan keadilan yang unversal. Asas-asas inilah yang dipakai untuk menguji legitimasi dan muatan keadilan suatu norma positif. Cara kerja aliran ini dalam suatu penelitian hukum menggunakan silogisme deduktif (doktrinal-deduktif). ${ }^{17}$ Selain itu, karena hukum dikonsepsikan sebagai asas kebenaran dan keadilan yang universal, maka ruang lingkupnya bersifat universal.

Dalam kaitannya dengan penelitian hukum, topik tentang Konvensi Internasional Anti Penyiksaan (International Convention Against Torture) dan Kriminalisasi Perdagangan Orang (human trafficking) sangat dekat dengan aliran hukum alam karena basis filsafati larangan penyiksaan dan kriminalisasi perdagangan orang berasal dari pemikiran hukum aliran hukum alam. Pertanyaan tentang mengapa negara-negara perlu meratifikasi Konvensi Internasional Anti Penyiksaan adalah karena dilatarbelakangi oleh nilai-nilai moralitas yang berlaku universal yang melintasi ruang dan waktu. Demikian juga pertanyaan tentang mengapa perdagangan orang perlu dilarang oleh hukum pidana. Ia merupakan perbuatan yang bertentangan dengan nilai-nilai kemanusiaan seorang manusia di manapun dan kapanpun ia berada.

\footnotetext{
hlm. 40 .

${ }^{16}$ Lili Rasjidi dan Ira Rasjidi, Dasar-dasar Filsafat dan Teori Hukum, Cetk, Ketujuh, Citra Aditya Bakti, 2001, hlm 47; John Finch, Introduction to Legal Theory, Edisi Kedua, Sweet \& Maxwell, London, 1974, hlm. 21.

17 Shidarta, "Pemetaan Aliran-aliran Pemikiran Hukum dan Konsekuensi Metodologisnya", dalam Sulistyowati Irianto dan Shidarta (Editor), Metode Penelitian Hukum Konstelasi dan Refleksi, Cetk. Pertama, Yayasan Obor, Jakarta, 2009, hlm. 161.
}

15 Otje Salman S, Filsafat Hukum (Perkembangan dan Dinamika Masalah), Refika Aditama, Bandung, 2009, 


\section{Realisme Hukum; Tesis Pemisahan Hukum dan Moral serta Kesatuan Hukum dan Fakta}

Berlawanan dengan tesis moralitas dan normatifitas aliran hukum alam adalah tesis realisme hukum. Jika hukum alam menyatukan hukum dan moral, positivisme empiris justru sebaliknya; hukum harus dipisahkan dari moral. Realisme hukum juga tidak memisahkan antara hukum dan fakta (reductive thesis), suatu pemikiran yang ditentang oleh aliran hukum alam. Bagi realisme hukum, hukum dapat direduksi sebagai fakta sosial atau hukum dilihat sebagai produk interaksi sosial.18

Dalam konteks aliran-aliran dalam filsafat hukum, realisme hukum Amerika Serikat adalah aliran yang memisahkan antara hukum dan moral dan lebih mementingkan fakta sosial. Realisme berarti berhubungan dengan dunia nyata, dunia sebagaimana ia nyata sekarang. Realisme hukum adalah suatu studi tentang hukum sebagai sesuatu yang benar-benar secara nyata dilaksanakan, daripada sekedar hukum sebagai sejumlah aturan yang hanya termuat dalam perundangundangan, tetapi tidak pernah dilaksanakan. ${ }^{19}$

Menurut penganut aliran ini, sifat normatif hukum harus dikesampingkan. Karena bagi mereka, hukum pada hakikatnya adalah manifestasi makna-makna simbolik para pelaku sosial. Pemaknaan demikian jelas sangat jauh dari nuansa filsafat, tetapi lebih menjurus kepada kombinasi dari berbagai disiplin ilmu, seperti sosiologi, psikologi, antropologi, dan ekonomi. ${ }^{20}$ Dalam kaitannya dengan penangangan suatu perkara, hakim harus selalu melakukan pilihan, asas mana yang akan diutamakan dan pihak mana yang dimenangkan. Keputusan tersebut sering mendahului ditemukan atau digarapnya peraturan-peraturan hukum yang menjadi landasannya. ${ }^{21}$ Oleh karenanya, kreatifitas hakim merupakan sentral dalam pembentukan hukum (judge-made law) ${ }^{22}$ sebab hukum bukan logika, melainkan pengalaman (the actual life of law has not been logic: it has been experience). ${ }^{23}$

\footnotetext{
18 Zulfadli Barus, "Analisis Filosofis tentang Peta Konseptual Penelitian Hukum Normatif dan Penelitian Sosiologis”, Jurnal Dinamika Hukum, Vol. 13 No 2, 2013, hlm. 311-312

${ }^{19}$ Achmad Ali, Sosiologi Hukum Kajian Empiris terhadap Pengadilan, Badan Penerbit Iblam, Jakarta, 2004, hlm. 41

${ }^{20}$ Shidarta, Karakteristik Penalaran Hukum dalam Konteks Keindonesiaa, CV. Utomo, Bandung, 2006, hlm. 273.

${ }_{21}$ Antonius Sudirman, Hati Nurani Hakim dan Putusannya Suatu Pendekatan dari Perspektif Ilmu Hukum Perilaku Kasus Hakim Bismar Siregar, PT. Citra Aditya Bakti, Bandung, 2007, hlm. 30

${ }^{22}$ Albert A. Ehrenzweic, Psychoanalytic Jurisprudence, Sijthoff/Oceana, Netherlands, 1971, hlm. 77

23 Albert W. Alschuler," From Blackstone To Holmes: The Revolt Against Natural Law", Pepperdine Law Review, 36, 2009, hlm 495-496; Margaret Davies, Asking The Law Question, Edisi Ketiga, Lawbook CO, Australia, 2008, hlm. 158
} 
Karena hukum menurut aliran realisme hukum dikonsepsikan sebagai pola perilaku dari pengalaman hakim di persidangan, maka metode penelitiannya adalah non-doktrinal induktif dengan ruang lingkup yang sempit (kasuistik), yaitu fakt-fakta sosial yang kasuistis. Dalam memutuskan kasus yang sedang ditangani, hakim tidak lagi berpedoman kepada norma-norma positif, melainkan beralih kepada realitas sosial dan kebutuhan masyarakat. Norma-norma positif ini tidak lagi digunakan oleh hakim jika tidak sesuai dengan realitas dan kebutuhan masyarakat. Selain itu, agar putusan hakim yang satu dengan yang lain tidak bertentangan satu sama lain, maka asas preseden menjadi pengikat sehingga ketidakpastian dan disparitas putusan dapat dicegah.

Contoh penelitian hukum yang menggunakan aliran realisme hukum adalah pengambilan sisa hasil panen (gresek/gasak) padi, randu, daun cengkeh dan hasil pertanian lainnya yang sudah menjadi kebiasan masyarakat desa di Jawa. ${ }^{24}$ Pertanyaannya adalah apakah warga masyarakat yang mengambil hasil pertanian tersebut dikategorikan sebagai mengambil barang kepunyaan orang lain secara melawan hukum sebagaimana maksud Pasal 362 KUHP? Tentu saja hakim tidak perlu melihat KUHP untuk memutus perkara tersebut, melainkan mendasarkan kepada kebiasaan masyarakat desa di Jawa yang sudah menjadi pola-pola perilaku yang ajeg. Kesimpulannya adalah bahwa mengambil sisa hasil pertanian bukanlah pencurian karena hal itu sudah menjadi kebiasaan masyarakat desa di Jawa. Dalam kasus ini, hakim berperan sebagai pembuat hukum (judge made law) ketimbang pelaksana undang-undang.

\section{Teori Hukum Murni; Tesis Pemisahan Hukum dan Moral serta Normatifitas}

Tesis yang dibangun oleh Kelsen dengan teori hukum murninya sebenarnya merupakan sintesis atas tesis aliran hukum alam dan positivisme empiris yang bertolak belakang. Dengan kata lain, pemikiran Kelsen merupakan jalan tengah dari dua aliran hukum tersebut. Di sini, Kelsen mengambil satu tesis aliran hukum alam yakni tesis keterpisahaan antara hukum dan fakta (normativity thesis) dan satu tesis positivisme empiris yakni keterpisahan antara hukum dan moral (separibility

${ }^{24}$ Widodo Dwi Putro, Kritik terhadap Paradigma Positivisme Hukum, Genta Publishing, Yogyakarta, 2011, hlm. 
of law and morality). Sebaliknya, Kelsen menolak tesis aliran hukum alam tentang kesatuan antara hukum dan moral dan satu tesis positivisme empiris tentang kesatuan antara hukum dengan fakta.

Kelsen berpandangan bahwa teori hukum harus dibedakan dari hukum itu sendiri, hukum harus seragam dalam arti dapat diterapkan pada semua waktu dan tempat, hukum harus dilepaskan dari anasir-anasir politik, psikologis, sosiologis, dan dipisahkan dari nilai-nilai moral/etis; 25 dengan kata lain hukum harus benarbenar murni, dan hukum merupakan pencerminan dari proposisi yang "seharusnya".26

Kelsen menghendaki dilepaskannya pemikiran metayuridis mengenai hukum sebagaimana dianut oleh para eksponen aliran hukum alam. ${ }^{27}$ Karena itu, setiap norma hukum haruslah eksis dalam alamnya yang objekif sebagai normanorma yang positif (all law is enacted law), ${ }^{28}$ ditegaskan sebagai wujud kesepakatakan kontraktual yang konkrit antara warga masyarakat. Hukum tidak lagi dikonsepsikan sebagai asas-asas moral metayuridis yang abstrak tentang hakikat keadilan, melainkan ius yang telah mengalami positivisasi sebagai lege atau lex, guna menjamin kepastian mengenai apa yang terbilang hukum dan apa pula yang sekalian normatif harus dinyatakan sebagai sebagai hal-hal yang bukan terbilang hukum. ${ }^{29}$

Selain terpisah dari moral, hukum juga terpisah dari fakta. Hukum adalah norma positif dalam sistem perundang-undangan dan terlepas dari fakta sosial. Apa yang telah dinormakan menjadi undang-undang adalah hukum sehingga keberadaannya sebagai institusi normatif yang memaksa. ${ }^{30}$

${ }^{25}$ Theo Huijbers, Filsafat Hukum dalam Lintasan Sejarah, Cetk. Keenambelas, Kanisius, Yogyakarta, 2012, hlm 156; Danang Hardianto, "Reorientation towards the Nature of Jurisprudence in Legal Research", Mimbar Hukum, Vol 26, No. 2, 2014, hlm. 342

${ }^{26}$ R.M.W Dias, Jurisprudence, Edisi Kelima, Butterworhts, London, 1985, hlm 358; R. M Dworkin, Filsafat Hukum Sebuah Pengantar, Diterjemahkan oleh Yudi Santoso, Merkid Press, Yogyakarta, 2007, hlm 2; Herman Bakir, Filsafat Hukum Desain dan Arsitektur Kesejarahan, PT. Refika Aditama, Bandung, 2007, hlm 330-334; Putera Astomo, "Perbandingan Pemikiran Hans Kelsen tentang Hukum dengan Gagasan Satjipto Rahardjo tentang Hukum Progresif Berbasis Teori Hukum", Yustisia, Edisi 90, 2014, hlm. 7-8

${ }_{27}$ Michael Steven Green, "Hans Kelsen And The Logic Of Legal Systems”, Alabama Law Review, 54, 365,2003, hlm. 366

${ }^{28}$ George P. Fletcher, Basic Concepts of Legal Thought, Oxford University Press, New York, 1996, hlm 33 hlm. 13

${ }^{29}$ Sutandyo Wignjosoebroto, "Permasalahan Paradigma dalam Ilmu Hukum”, Jurnal Wacana, Vol 6, 2000,

${ }^{30}$ Hanoch Dagan \& Roy Kreitner”, The Character of Legal Theory”, Cornell Law Review, 96, 2011, hlm. 681 
Validitas suatu norma tidak terletak pada kesesuaian antara norma itu dengan kenyataan, melainkan kepada norma yang terletak di atasnya sampai pada norma dasar (grundnorm) yang berfungsi sebagai sumber keharusan dalam bidang hukum. Norma dasar ini dapat dirumuskan dalam bentuk suatu kaidah hukum yang dianggap sebagai yang tertinggi dalam bidang hukum. Kaidah itu berbunyi sebagai berikut: orang harus menyesuaikan diri dengan apa yang ditentukan (man soll sich so verhalten wie die verfassung vorschreibt). Bagi Kelsen, norma dasar itu semata-mata berfungsi sebagai syarat transendental-logis berlakunya seluruh tata hukum. Itu berarti bahwa keharusan dan kewajiban yang berkaitan dengan hukum tidak berasal dari isi kaidah hukum yang tertentu, melainkan dari segi formalnya. ${ }^{31}$

Dua tesis teori hukum murni Kelsen tersebut, wajar jika metode penelitiannnya menggunakan metode doktrinal-deduktif dalam lingkup partikular. Dikatakan partikular karena ruang lingkup keberlakuan norma-norma positif itu hanyalah sebatas wilayah kekuasaan penguasa yang bersangkutan. Teori hukum murni tidak mengasumsikan ada norma-norma yang berlaku universal karena apa yang menjadi hukum selalu merupakan produk pemegang kekuasaan politik. Selain itu, metode penelitian dalam perspektif teori hukum murni akan senantiasa menjadikan norma-norma positif sebagai sumber utama untuk menjustifikasi setiap permasalahan hukum. Norma-norma positif yang diasumsikan benar dengan sendirinya itu selalu ditempatkan sebagai premis mayor. Rumusan premis mayor inilah yang menentukan ke mana arah konklusi dari silogisme deduktif tersebut. ${ }^{32}$

Dalam kaitan dengan penelitian hukum, contoh kasus gresek/gasak di atas akan berbeda jika menggunakan tesis dalam teori hukum murni Kelsen. Jawaban atas pertanyaan tentang apakah warga masyarakat yang mengambil hasil pertanian tersebut dikategorikan sebagai mengambil barang kepunyaan orang lain secara melawan hukum sebagaimana maksud Pasal 362 KUHP bergantung kepada kesesuaian antara premis minor berupa fakta bahwa warga masyarakat desa di Jawa telah mengambil sisa hasil panen kepunyaan orang lain dengan premis mayor berupa unsur-unsur delik dalam Pasal 362 KUHP. Jika kesimpulannya adalah

\footnotetext{
31 Theo Huijbers, Op. Cit., hlm. 158

32 Shidarta, Pemetaan...Op. Cit., hlm. 160
} 
sesuai, maka perbuatan warga tersebut dikategorikan sebagai pencurian. Di sini, hakim berperan sebagai pelaksana undang-undang. Apa yang termaktub dalam Pasal 362 KUHP akan dicocokkan oleh hakim dengan kasus yang sedang ditangani. Jika ada kesesuaian, maka hakim tinggal memutus bahwa perbuatan seseorang terbukti memenuhi unsur dalam Pasal 362 KUHP.

\section{Mazhab Sejarah; Tesis Moralitas dan Kesatuan Hukum dan Fakta}

Tesis yang dibangun mazhab sejarah yang dikembangkan oleh Savigny di satu sisi memiliki persamaan sekaligus perbedaan dengan aliran hukum alam, dan di sisi lain juga memiliki kemiripan dengan positivisme empiris. Persamaan dengan aliran hukuum alam adalah terletak pada penyatuan antara hukum dan moral (morality thesis). Baik aliran hukum alam maupun mazhab sejarah sama-sama tidak memisahkan antara hukum dan moral. Sedangkan perbedaannya, lingkup moral menurut mazhab sejarah tidak bersifat universal sebagaimana dalam tesis aliran hukum alam, melainkan bersifat partikular. Keberadaan setiap hukum termasuk nilai-nilai moral adalah berbeda, bergantung kepada tempat dan waktu berlakunya hukum. Hukum dipandang sebagai penjelmaan dari jiwa atau rohani suatu bangsa (volksgeist). ${ }^{33}$ Apa yang dianggap bermoral atau tidak bermoral berbeda antara satu bangsa dengan bangsa lain bergantung kepada jiwa bangsa itu.

Edgar Bodenheimer dengan mengutip pemikiran Savigny mengatakan bahwa: ${ }^{34}$

The law was not something that should be made arbitrarily and deliberately by a lawmaker. Law was a product of "internal, silently-operating forces". It was deeply routed in the past of a nation, and its true sources were popular faith, custom, and "the common consciousness of the people". Like the language, the constitution, and the character of a nation, by "its national spirit" (volksgeist).

Hukum, dengan demikian, harus bersumber dari kebiasan dan kesadaran umum masyarakat. Aturan hukum yang dibuat dan diterapkan hendaknya merupaan endapan dari jiwa hukum rakyat. Karena hanya dengan inilah, aturan itu bisa diterapkan dan berfungsi dengan baik di masyarakat. Hukum tumbuh dan

\footnotetext{
33 Absori, Kelik Wardiono, dan Saepul Rochman, Hukum Profetik Kritik terhadap Paradigma Non-Sistematik, Genta Publishing, Yogyakarta, 2015, hlm. 104

${ }^{34}$ Edgar Bodenheimer, Jurisprudence The Philosophy and Method of the Law, Harvard University Press, USA, 1978, hlm. 71
} 
berkembang sejalan dengan perkembangan rakyat, dan akhirnya punah dengan berakhirnya suatu bangsa. ${ }^{35}$

Mazhab sejarah juga tidak memisahkan antara hukum dengan fakta (reductive thesis) sebagaimana tesis positivisme empiris. Mazhab sejarah meyakini hukum tidak perlu dibuat karena ia tumbuh dan berkembang mengikuti masyarakat. Organisme hukum yang hidup ini mengejawantah dalam perilaku-perilaku sosial dalam skala makro. Penelitian hukum dalam mazhab sejarah mutlak membutuhkan data lapangan dengan mengamati praktik-praktik hukum masyarakat dari waktu ke waktu. Oleh karena itu, antara hukum dengan fakta tidak dapat dipisahkan karena hukum adalah pola perilaku yang terlembagakan.

Berdasarkan dua tesis mazhab sejarah tersebut, metode penelitian menurut mazhab ini memadukan dua pendekatan sekaligus yaitu silogisme doktrinaldeduktif (hukum sebagai penjelmaan dari jiwa atau rohani suatu bangsa) dan nondoktrinal-induktif (organisme hukum yang hidup mengejawantah dalam perilakuperilaku sosial dalam skala makro) ${ }^{36}$ sehingga ruang lingkupnya partikular.

Penelitian tentang penyelesaian perkara pidana berbasis hukum adat kental dengan tesis mazhab sejarah. Di sini, peneliti tidak perlu membandingkan dengan model penyelesaian sengketa di negara lain karena yang hendak diketahui adalah nilai-nilai kearifan lokal masyarakat Indonesia dalam menyelesaikan perkara pidana. Atau, penelitian tentang fondasi filsafat ilmu hukum Pancasila juga berangkat dari tesis mazhab sejarah. Peneliti akan mengkaji sejarah perumusan Pancasila dan pembukaan Undang-undang Dasar 1945, falsafat dan cita hukum bangsa Indonesia, pandangan hidup bangsa Indonesia. Semua itu menjadi bahan dalam mengkonstruksi fondasi filsafat ilmu hukum Pancasila.

\section{American Sociological Jurisprudence; Tesis Pemisahaan Hukum dan Moral serta Kesatuan Hukum dan Fakta}

American Sociological Jurisprudence lahir sebagai jalan tengah atas ketegangan antara positivisme hukum dan mazhab sejarah. Jika positivisme hukum mengkonsepsikan hukum sebagai norma positif dalam sistem perundangundangan dan mengabaikan keberadaan data lapangan, maka realisme hukum

\footnotetext{
${ }^{35}$ Ibid., hlm. 72

${ }^{36}$ Shidarta, Karakteristik Penalaran Hukum dalam Konteks Keindonesiaan, CV. Utomo, Bandung, 2006, hlm. 259
} 
justru membutuhkan data lapangan karena hukum dikonsepsikan sebagai polapola perilaku sosial yang terlembagakan. Perbedaan mengenai konsep hukum kedua aliran ini 'didamaikan' oleh American Sociological Jurisprudence yang memandang bahwa hukum yang baik adalah hukum yang sesuai dengan hukum yang hidup di masyarakat. Sesuai disini berarti bahwa hukum itu mencerminkan nilai-nilai yang hidup di masyarakat. ${ }^{37}$ Hukum positif dalam sistem perundangundangan itu hanya akan efektif jika selaras dengan hukum yang hidup dalam masyarakat. ${ }^{38}$ Aliran ini mengkonsepsikan hukum sebagai putusan hakim inconcreto. 39

American Sociological Jurisprudence tetap menjadikan norma positif dalam sistem perundang-undangan sebagai acuan, namun tidak dipandang sebagai hukum yang hakiki, melainkan sebagai panduan saja untuk menyelesaikan suatu kasus konkrit. Tesis yang dibangun aliran ini adalah pemisahan antara hukum dengan moral sebagai konsekuensi dari konsepsi hukum sebagai norma positif dalam sistem perundang-undangan. Pada saat yang sama, aliran ini juga tidak memisahkan antara hukum dengan fakta karena putusan hakim haruslah sesuai dengan nilai-nilai yang hidup dalam masyarakat. Dengan kata lain, basis putusan hakim tidak semata-mata norma positif dalam sistem perundang-undangan, melainkan nilai atau kenyataan yang hidup dan dipraktikkan dalam masyarakat.

Dalam konteks pendekatan dalam penelitian hukum, American Sociological Jurisprudence memadukan dua pendekatan sekaligus secara bersamaan, yaitu pola bottom-up yang non-doktrinal induktif dan pola top-down yang doktrinal deduktif. ${ }^{40}$ Meskipun pendekatan dalam penelitian aliran ini sama dengan pendekatan penelitian mazhab sejarah, tetapi keduanya berbeda. Pertama, yang disebut doktrinal deduktif bukanlah jiwa bangsa (volksgeist), melainkan norma positif dalam sistem perundang-undangan. Kedua, yang disebut non-doktrinal induktif bukanlah pola-pola perilaku sosial yang terlembagakan, melainkan putusan hakim

${ }^{37}$ Lili Rasjidi dan Ira Rasjidi, Dasar-dasar Filsafat dan Teori Hukum, Cetk, Ketujuh, PT. Citra Aditya Bakti, Bandung, 2001, hlm. 66.

38 Otje Salman, Filsafat Hukum (Perkembangan dan Dinamika Masalab), Refika Aditama, Bandung, 2009, hlm. 72

${ }^{39}$ Shidarta, Karakteristik...Op.Cit., hlm. 268.

40 Ibid., hlm. 266. 
(judge made law). Jadi, lingkup American Sociological Jurisprudence adalah kasuistik, sedangkan mazhab sejarah partikular.

Contoh penelitian hukum yang menggunakan tesis American Sociological Jurisprudence adalah perkawinan yang dilangsungkan pada masa iddah. Pertanyaannya adalah apakah perkawinan yang dilangsungkan pada masa iddah tidak sah atau batal? Untuk menjawab pertanyaan ini, peneliti perlu melakukan dua hal secara bersamaan (simultan), yaitu mengetahui hukum perkawinan yang dilangsungkan pada masa iddah menurut kebiasaan masyarakat dan menurut norma positif dalam sistem perundang-undangan. Jika kedua instrumen hukum menyimpulkan bahwa perkawinan yang dilangsungkan pada masa iddah tidak sah, maka peneliti menyimpulkan bahwa perkawinan tersebut tidak sah/batal. ${ }^{41}$

\section{Utilitarianisme; Tesis Pemisahaan Hukum dan Moral serta Kesatuan Hukum dan Fakta}

Aliran utilitarianisme merupakan aliran yang dipelopori oleh tiga eksponen utamanya yaitu Jeremy Bentham, John Stuar Mill, dan Rudolf von Jhering. Dengan memegang prinsip bahwa manusia akan melakukan tindakan untuk mendapatkan kebahagiaan yang sebesar-besarnya dan mengurangi penderitaan, Bentham mencoba menerapkannya di bidang hukum. Baik buruknya suatu perbuatan diukur apakah perbuatan itu mendatangkan kebahagiaan atau tidak. Demikian pula dengan perundang-undangan, baik buruknya ditentukan pula oleh ukuran tersebut. Oleh karena itu, undang-undang yang memberikan kebahagiaan pada bagian terbesar masyarakat akan dinilai sebagai undang-undang yang baik. ${ }^{42}$

N.E. Simmonds mengatakan:

The basic principle of utility required us to weight up the consequences, in terms of happiness and unhappiness, of various alternative actions, and choose that action which would, on balance, have the best consequences, in the sense of producing the largest net balance of happinees. ${ }^{43}$

Tesis utilitarianisme sama dengan tesis positivisme hukum dari dimensi ontologi karena kedua aliran ini memandang hukum sebagai norma positif dalam

${ }^{41}$ Contoh penelitian hukum ini dimodifikasi dari Shidarta, Ibid., hlm 268-269

${ }^{42}$ Lili Rasjidi dan Iran Rasjidi, Dasar-dasar..., Op. Cit., hlm. 64

${ }^{43}$ N.E. Simmons, Central Issues in Jurisprudence Justice, Law and Rights, Sweet \& Maxwell, London, 1986, hlm. 
sistem perundang-undangan. Hukum, dengan demikian, harus dipisahkan dengan moral (separibility thesis). Perbedaan utilitarianisme dengan positivisme justru terletak pada dimensi epistemologis dan aksiologi. Utilitarianisme tidak sekedar mementingkan tujuan kepastian hukum. Jika norma-norma positif hanya diarahkan pada pencapaian kepastian, maka pekerjaan telah berakhir begitu suatu keputusan/putusan hukum selesai ditetapkan. Utilitarianisme memandang dimensi kemanfaatan dari keputusan/putusan hukum itu juga perlu diperhatikan untuk mengukur seberapa jauh keberlanjutan suatu norma positif dapat terus dipertahankan. ${ }^{44}$ Dengan kata lain, norma positif dalam sistem perundangundangan itu harus diuji dalam lapangan kenyataan. Karena ada dimensi uji dalam lapangan kenyataan inilah, maka tesis lain utilitarianisme adalah tidak memisahkan antara hukum dan fakta.

Mengetahui kedua tesis utilitarianisme di atas, dapat diketahui bahwa pendekatan dalam penelitian menurut utilitarianisme adalah gabungan dari doktrinal deduktif dengan gerakan top-down dan non-doktrinal induktif dengan gerakan bottom-up. Yang pertama terkait konsepsi hukum sebagai norma positif dalam sistem perundang-undangan, sedangkan yang kedua berhubungan dengan efektifitas dan kemanfaatan norma positif tersebut di dalam masyarakat. Gerakan top-down dan bottom-up tidak simultan, tetapi berjalan linier. Setiap peraturan yang dikonsepsikan sebagai perintah penguasa itu memerlukan waktu kemudian untuk dievaluasi dan dinilai baik buruknya. Ini berarti, prinsip efficacy tidak dapat mempengaruhi prinsip validity. Suatu norma positif tetap absah, terlepas hasil evaluasinya menunjukkan aturan itu tidak membawa manfaat bagi sebagian besar masyarakat yang terikat norma tersebut (the greatest happiness of the greatest number). Gerakan bottom-up terkait keharusan agar produk hukum yang dibuat pembentuk undang-undang dinilai responsif. ${ }^{45}$ Dengan kata lain, gerakan bottom-up sebagai bentuk feed-back bagi norma positif dalam sistem perundang-undangan (gerakan top-down).

${ }^{44}$ Shidarta, Pemetaan..., Op. Cit., hlm. 164

${ }^{45}$ Shidarta, Karakteristik..., Op. Cit., hlm. 253 
Dalam konteks penelitian hukum, penelitian tentang pemakaian helm SNI bagi pengendara sepeda motor dapat dianalisis dengan menggunakan tesis aliran utilitarianisme. Pertanyaan pokoknya adalah apakah kewajiban memakai helm SNI bagi pengendara sepeda motor dalam Undang-Undang Nomor 22 Tahun 2009 tentang Lalu Lintas dan Angkutan Jalan memberikan kemanfaatan kepada mereka di jalan raya? Peneliti akan menganalisis kasus-kasus kecelakaan pengendara sepeda motor di jalan dalam rentang waktu yang agak lama dengan menfokuskan pada bagian anggota tubuh mana yang rentan mengalami luka. Jika kesimpulan penelitian menyatakan bahwa sebagian besar kecelakaan mengenai kepala pengendara sepeda motor, maka kewajiban memakai helm SNI bermanfaat bagi pengendara sepeda motor untuk melindungi kepalanya dari kemungkinan benturan yang menyebabkan kepalanya luka.

\section{Penutup}

Tiap-tiap aliran hukum yang berkembang dalam filsafat hukum memiliki tesis yang berbeda satu dengan lain yang berimplikasi pada perbedaan metodologisnya. Tesis aliran hukum alam adalah tesis moralitas dan normatifitas. Hukum alam menyatukan antara hukum dan moral, tapi memisahkan antara hukum dengan fakta. Metodologi penelitian menurut hukum alam bersifat doktrinal deduktif dengan lingkup yang universal. Sedangkan tesis positivisme empiris justru memisahkan antara hukum dan moral serta menyatukan hukum dan fakta. Metodologi penelitian menurut positivisme empiris adalah nondoktrinal induktif karena hukum dikonsepsikan sebagai manifestasi makna-makna simbolik para pelaku sosial.

Tesis teori hukum murni Kelsen merupakan sintesis dari tesis hukum alam dan positivisme empiris. Tesis normatifitas dari hukum alam dan tesis pemisahan antara hukum dan moral dari positivisme empiris diambil dan dijadikan tesis teori hukum murni. Metodologi penelitiannya adalah doktrinal deduktif. Lingkup kajiannya bersifat partikular karena hukum dikonsepsikan sebagai norma positif dalam sistem perundang-undangan yang terikat dengan ruang dan waktu. Sedangkan tesis mazhab sejarah adalah kesatuan antara hukum dan moral serta kesatuan antara hukum dan fakta, sehingga metodologi penelitiannya merupakan 
gabungan dari doktrinal deduktif dan non-doktrinal induktif. Nilai-nilai moral menurut mazhab sejarah dibatasi pada jiwa tiap-tiap bangsa (volksgeist) sehingga lingkupnya bersifat partikular.

Tesis American Sociological Jurisprudence adalah pemisahan antara hukum dan moral serta penyatuan antara hukum dan fakta. Metodologi penelitiannya berupa doktrinal deduktif dan non-doktrinal induktif yang dilakukan secara simultan dengan lingkup yang kasuistik. Sebagai sintesis dari positivisme hukum dan mazhab sejarah, American Sociological Jurisprudence berbeda dengan positivisme hukum dan mazhab sejarah. Jika positivisme hukum menjadikan norma positif dalam sistem perundang-undangan sebagai yang utama, American Sociological Jurisprudence justru menempatkannya sebagai ancar-ancar saja untuk menyelesaikan suatu kasus konkrit. Aliran ini juga membatasi konsep hukum sebagai putusan hakim (judge made law). Sedangkan tesis utilitarianisme adalah pemisahan antara hukum dan moral serta kesatuan antara hukum dan fakta. Konsep hukum menurut aliran utilitarianisme sama dengan konsep hukum menurut teori hukum murni, yaitu norma positif dalam sistem perundang-undangan. Hal yang membedakan pada dimensi epistemologi dan aksiologi di mana utilitarianisme menggunakan metodologi doktrinal deduktif dan non-doktrinal induktif secara linier. Norma positif dalam sistem perundang-undangan itu harus diuji dalam lapangan kenyataan. Oleh karena itu, nilai kepastian hukum diikuti dengan nilai kemanfaatan. Dalam kaitannya dengan kotak yang sengaja tidak diisi Stanley L. Paulson, tesis-tesis mazhab sejarah, American Sociological Jurisprudence, dan utilitarianisme sebenarnya dapat dimasukkan ke dalam kotak tersebut meskipun antara ketiganya tidak sama persis, sebagaimana terlihat pada bagan di bawah ini.

\begin{tabular}{lll}
$\begin{array}{l}\text { Fakta Hukum dan } \\
\text { Hukum dan Moral }\end{array}$ & $\begin{array}{c}\text { Tesis Normatifitas } \\
\text { (keterpisahaan hukum } \\
\text { dan fakta) }\end{array}$ & $\begin{array}{l}\text { Tesis Reduktif } \\
\text { (Kesatuan hukum dan } \\
\text { fakta) }\end{array}$ \\
\hline $\begin{array}{l}\text { Tesis Moralitas } \\
\text { (Kesatuan hukum dan } \\
\text { moral) }\end{array}$ & Teori Hukum Alam & $\begin{array}{l}\text { Mazhab Sejarah } \\
\text { American Sociological } \\
\text { Jurisprudence }\end{array}$ \\
$\begin{array}{l}\text { Tesis Separibilitas } \\
\text { (Keterpisahaan hukum } \\
\text { dan moral) }\end{array}$ & $\begin{array}{l}\text { Teori Hukum Murnitarianisme } \\
\text { Pesitivisme Empiris }\end{array}$ \\
\hline
\end{tabular}




\section{Daftar Pustaka}

\section{Buku}

Absori, Kelik Wardiono, dan Saepul Rochman, Hukum Profetik Kritik terhadap Paradigma Non-Sistematik, Genta Publishing, Yogyakarta, 2015.

Albert A. Ehrenzweic, Psychoanalytic Jurisprudence, Sijthoff/Oceana, Netherlands, 1971.

Ali, Achmad, Sosiologi Hukum Kajian Empiris terhadap Pengadilan, Badan Penerbit Iblam, Jakarta, 2004.

Ata Ujan, Andre, Filsafat Hukum, Kanisius, Yogyakarta, 2009.

Bakir, Herman, Filsafat Hukum Desain dan Arsitektur Kesejarahan, PT. Refika Aditama, Bandung, 2007.

Bodenheimer, Edgar, Jurisprudence The Philosophy and Method of the Law, Harvard University Press, USA, 1978.

Davies, Margaret, Asking the Law Question, Edisi Ketiga, Lawbook CO, Australia, 2008.

Dias, R.M.W., Jurisprudence, Edisi Kelima, Butterworhts, London, 1985.

Dworkin, R. M., Filsafat Hukum Sebuah Pengantar, Diterjemahkan oleh Yudi Santoso, Merkid Press, Yogyakarta, 2007.

Finch, John, Introduction to Legal Theory, Edisi Kedua, Sweet \& Maxwell, London, 1974.

G. Murphy, Jeffrie, dan Jules L. Coleman, Philosophy of Law an Introduction to Jurisprudence, Edisi Revisi, Westview Press, London, 1990. Jimly Asshiddiqie dan M. Ali Safa'at, Teori Hans Kelsen tentang Hukum, Mahkamah Konstitusi, Jakarta, 2006.

Huijbers, Theo, Filsafat Hukum dalam Lintasan Sejarah, Cetk. Keenambelas, Kanisius, Yogyakarta, 2012.

Kelsen, Hans, Introduction to the Problem of Legal Theory, diterjemahkan oleh Bonnie Litschewski Paulson dan Stanley L. Paulson, Clarendon Press, Oxford New York, 1992.

Sudirman, Antonius, Hati Nurani Hakim dan Putusannya Suatu Pendekatan dari Perspektif Ilmu Hukum Perilaku Kasus Hakim Bismar Siregar, PT. Citra Aditya Bakti, Bandung, 2007.

Patterson, Dennis, (editor), A Companion to Philosophy of Law and Legal Theory, Blackwell Publishers, United Kingdom, 1999.

P. Fletcher, George, Basic Concepts of Legal Thought, Oxford University Press, New York, 1996.

Rasjidi, Lili dan Ira Rasjidi, Dasar-dasar Filsafat dan Teori Hukum, Cetk, Ketujuh, PT. Citra Aditya Bakti, Bandung, 2001. 
Salman S., Otje, Filsafat Hukum (Perkembangan dan Dinamika Masalah), Refika Aditama, Bandung, 2009.

Shidarta, "Pemetaan Aliran-aliran Pemikiran Hukum dan Konsekuensi Metodologisnya", dalam Sulistyowati Irianto dan Shidarta (Editor), Metode Penelitian Hukum Konstelasi dan Refleksi, Cetk. Pertama, Yayasan Obor, Jakarta, 2009

, Karakteristik Penalaran Hukum dalam Konteks Keindonesiaan, CV. Utomo, Bandung, 2006.

Simmons, N.E., Central Issues in Jurisprudence Justice, Law and Rights, Sweet \& Maxwell, London, 1986.

\section{Jurnal}

Alschuler, Albert W.," From Blackstone To Holmes: The Revolt Against Natural Law", Pepperdine Law Review, 36, 2009.

Astomo, Putera, "Perbandingan Pemikiran Hans Kelsen tentang Hukum dengan Gagasan Satjipto Rahardjo tentang Hukum Progresif Berbasis Teori Hukum", Yustisia, Edisi 90, 2014.

Barus, Zulfadli, "Analisis Filosofis tentang Peta Konseptual Penelitian Hukum Normatif dan Penelitian Sosiologis", Jurnal Dinamika Hukum, Vol. 13 No 2, 2013.

Dagan, Hanoch, \& Roy Kreitner", The Character of Legal Theory", Cornell Law Review, 96, 2011.

Green, Michael Steven, "Hans Kelsen And The Logic Of Legal Systems", Alabama Law Review, 54, 365,2003.

Hardianto, Danang, "Reorientation towards the Nature of Jurisprudence in Legal Research", Mimbar Hukum, Vol 26, No. 2, 2014.

Luthan, Salman, "Dialektika Hukum dan Moral dalam Perspektif Filsafat Hukum”, Jurnal Hukum Ius Quita Iustum, No. 4, Vol 19, 2012

Rappaport, Aaron, "The Logic of Legal Theory: Reflections on the Purpose and Methodology of Jurisprudence", Mississippi Law Journal, 73, 2004.

Wignjosoebroto, Sutandyo, "Permasalahan Paradigma dalam Ilmu Hukum”, Jurnal Wacana, Vol 6, 2000. 